DOI: https://doi.org/10.47405/mjssh.v6i11.1170

\begin{tabular}{|c|c|}
\hline & Malaysian Journal of Social Sciences and Humanities (MJSSH) \\
\hline Malaysian Journal of & Volume 6, Issue 11, November 2021 \\
\hline (MJ-SSH) & e-ISSN : 2504-8562 \\
\hline & $\begin{array}{l}\text { Journal home page: } \\
\text { www.msocialsciences.com }\end{array}$ \\
\hline
\end{tabular}

\title{
Kepuasan Kediaman Perumahan Kos Rendah di Kota Bharu, Kelantan
}

\author{
Norazmawati Md. Sani ${ }^{1}$, Siti Nur Fatihah Che Ghani ${ }^{1}$ \\ ${ }_{1}^{1}$ Pusat Pengajian Perumahan, Bangunan dan Perancangan, Universiti Sains Malaysia (USM), 11800 USM, Pulau \\ Pinang, Malaysia
}

Correspondence: Norazmawati Md. Sani (norazmawati@usm.my)

\begin{abstract}
Abstrak
Perumahan merupakan sejenis keperluan asas yang sangat penting untuk manusia selain menjadi agenda utama setiap negara. Dalam masa yang sama, tahap kepuasan terhadap perumahan juga sangat penting diambil kira dalam pembangunan sesebuah perumahan terutamanya perumahan kos rendah yang memerlukan kesesuaian harga dan keselesaan dari segi ciri perumahan, persekitaran, penyelenggaraan, kerja pembinaan dan sebagainya. Walau bagaimanapun, perumahan kos rendah sering dikaitkan dengan isu perumahan yang kurang memuaskan dan menyebabkan penduduk yang mendiami perumahan kos rendah itu tidak berpuas hati terhadap ciri-ciri perumahan tersebut. Objektif kajian ini adalah untuk mengenal pasti faktor-faktor tahap kepuasan perumahan kos rendah dan untuk menentukan tahap kepuasan perumahan kos rendah. Kawasan kajian ialah di flat Buluh Kubu dan perumahan teres kos rendah di Pengkalan Chepa, Kota Bharu, Kelantan. Saiz sampel ialah seramai 560 orang responden iaitu responden di flat Buluh Kubu seramai 260 responden dan responden di perumahan teres kos rendah di Pengkalan Chepa seramai 300 responden. Dapatan kajian dianalisis secara kuantitatif dengan menggunakan kaedah analisis kekerapan dan analisis deskriptif. Hasil kajian ini menunjukkan bahawa faktor-faktor tahap kepuasan perumahan kos rendah ialah kriteria perumahan di dalam bangunan dan di luar bangunan iaitu unit dalaman, ukuran unit, berdekatan kemudahan awam, penyelenggaraan dan keadaan persekitarannya, kelengkapan kebersihan, jenis rumah, bahan binaan, susun atur dalaman unit, kualiti kerja dan struktur rumah. Manakala bagi tahap kepuasan perumahan kos rendah, hasil kajian mendapati responden di kedua-dua kawasan kajian tidak berpuas hati terhadap keadaan balkoni, ruang dobi, taman permainan, sistem penyelenggaraan tong sampah, atap, perilaku penduduk yang tidak menjaga kebersihan dan bangunan rumah yang pecah serta retak.
\end{abstract}

Kata kunci: kemampuan, pemilikan rumah, golongan belia, persampelan rawak, skim perumahan

\section{Residential Satisfaction of Low Cost Housing in Kota Bharu, Kelantan}

\begin{abstract}
Housing is one of the basic needs that are very important for human beings besides being the main agenda for every country. At the same time, the level of satisfaction with housing is also very important to take into account in the development of a housing, especially low-cost housing that requires appropriate price and comfort in terms of housing characteristics, environment, maintenance, construction work and so on. However, low-cost housing is often associated with unsatisfactory housing issues and causes residents living in low-cost housing to be dissatisfied with the characteristics of the housing. The objective of this study was to identify the factors of low-cost housing satisfaction level and to determine the low cost housing satisfaction level. The study area is in Buluh Kubu flats
\end{abstract}


and low-cost terrace housing in Pengkalan Chepa, Kota Bharu, Kelantan. The total of sample size of respondents was 560, with 260 respondents in Buluh Kubu flats and 300 respondents in low-cost terrace housing in Pengkalan Chepa, Kota Bharu, Kelantan. The findings of the study were analyzed quantitatively using the methods of frequency analysis and descriptive analysis. The results of this study show that the factors of low-cost housing satisfaction level are the criteria of housing inside and outside the building, namely indoor units, unit size, proximity to public facilities, maintenance and environmental conditions, sanitary fittings, type of house, building materials, layout unit interior, work quality and house structure. While for the level of satisfaction of low-cost housing, the results of the study found that respondents in both study areas were dissatisfied with the condition of balconies, laundry rooms, playgrounds, garbage bin maintenance system, roofs, residents who do not maintain cleanliness and broken and cracked house buildings.

Keywords: affordability, home ownership, youth, random sampling, housing scheme

\section{Pengenalan}

Kediaman merupakan aspek yang sangat penting bagi manusia kerana kediaman merupakan keperluan asas dalam kehidupan manusia. Setiap rumah yang didiami dapat memberikan kepuasan yang baik kepada penghuninya. Perumahan yang selesa merangkumi pelbagai aspek seperti aspek kualiti rumah, harga yang berpatutan, akses yang mudah, ciri kejiranan yang baik dan aspek keselamatan yang digunakan dalam pemilihan untuk memiliki rumah yang selesa (Shadiya, 2016). Hal ini disokong oleh Russell (2008) yang menyatakan bahawa kekurangan tahap kepuasan penduduk terhadap perumahan dapat memberi kesan negatif terhadap kesejahteraan kepada individu kerana berlakunya perpindahan penduduk, kejiranan yang tidak mesra, masyarakat miskin yang memberi kesan negatif terhadap pendidikan anak-anak. Oleh hal demikian, kepuasan perumahan boleh dicapai selepas mengambil kira pelbagai faktor antaranya lokasi rumah, harga rumah, reka bentuk rumah, aspek kejiranan yang baik, persekitaran perumahan yang selamat dan pelbagai lagi faktor lain yang memberi kepuasan perumahan. Menurut Mohammad et al. (2010) menyatakan bahawa lokasi perumahan kos rendah yang berhampiran dengan pusat membeli belah harus dipertimbangkan oleh pihak agensi perumahan awam untuk meningkatkan kepuasan kediaman penduduk selain dapat memenuhi keperluan penduduk yang tinggal dengan keluarga yang besar. Kepuasan perumahan adalah perlu agar penghuni dapat menikmati kehidupan dengan berkualiti dan lebih selesa.

\section{Sorotan Literatur}

Keadaan perumahan yang baik adalah merujuk pada kedua-dua ciri fizikal kediaman dan tahap kepuasan terhadap perumahan yang didiaminya. Jika keadaan perumahan itu adalah baik, maka kos perumahan akan menjadi perhatian utama isi rumah di kebanyakan Negara untuk membuat keputusan memiliki sesebuah rumah. Kepuasan perumahan pula merupakan salah satu komponen penting untuk mencapai kualiti kehidupan yang baik. Menurut Gabriel dan Bowling (2004), maksud kualiti hidup dari segi perumahan ialah sesebuah rumah yang mampu mencapai ciri-ciri tertentu seperti ciri bangunan yang sempurna, hubungan kejiranan yang baik, pengurusan dan penyelenggaraan yang berkesan, aksesibiliti yang mudah, kawasan perumahan yang selamat dan seronok serta dapat melakukan aktiviti sosial dan kemasyarakatan bersama serta mempunyai pendapatan yang tetap dan mampu mengawal kehidupan. Namun sekiranya penduduk masih tidak berpuas hati dengan persekitaran kawasan perumahan, hal ini berkemungkinan disebabkan oleh kekurangan faktor kemudahan, keselamatan yang tidak terjamin dan berlaku pencemaran yang akan menyebabkan penduduk tidak selesa dan rasa tidak selamat. Mengikut Zadkarim (2011), sesebuah perumahan yang dapat memberi kepuasan kepada penduduk adalah jenis perumahan yang mampu untuk mencapai kualiti kehidupan. Ghani dan Nurwati (2012) menyimpulkan bahawa petunjuk penting untuk mencapai kualiti kehidupan adalah dengan memberi tahap kepuasan perumahan kepada penduduk. Hal ini disokong oleh Russel (2008) yang menyatakan bahawa kekurangan tahap kepuasan penduduk terhadap perumahan dapat memberi kesan negatif terhadap kesejahteraan kepada individu kerana berlakunya 
perpindahan penduduk, kejiranan yang tidak mesra, masyarakat miskin serta memberi kesan negatif terhadap pendidikan anak-anak. Liu (1999), menyatakan dalam memenuhi kepuasan terhadap kualiti perumahan adalah dengan cara pengurusan dan penyelenggaraan dilakukan dengan baik, mempunyai reka bentuk yang menyamankan seperti pengudaraan dan pencahayaan, kebersihan, pembuangan sampah secara terurus, mempunyai kawasan yang selamat dan sebagainya. Raja Noriza (2010) juga bersetuju bahawa faktor-faktor yang menentukan tahap kepuasan perumahan juga merangkumi struktur dan ciri fizikal bangunan. Oleh hal demikian, kepuasan terhadap kediaman yang dipilih merupakan faktor utama dalam menentukan pilihan memiliki rumah kos rendah di Kota Bharu, Kelantan.

\section{Metod Kajian}

Metodologi kajian yang digunakan sebagai panduan agar kajian dapat dijalankan secara tersusun dan lancar. Kawasan kajian ialah di flat Buluh Kubu dan perumahan teres kos rendah di Pengkalan Chepa, Kota Bharu, Kelantan. Saiz sampel ialah seramai 560 orang responden iaitu responden di flat Buluh Kubu seramai 260 responden dan responden di perumahan teres kos rendah di Pengkalan Chepa seramai 300 responden. Dapatan kajian dianalisis secara kuantitatif dengan menggunakan kaedah analisis kekerapan dan analisis deskriptif.

Penggunaan jadual Krejcie et al. (1970) digunakan disebabkan saiz sampel yang ditunjukkan adalah sesuai dengan jumlah penduduk sasaran dan tahap ketepatannya sebanyak $95 \%$ yang juga digunakan dalam kajian Norazmawati (2007). Keperluan untuk sampel statistik yang mewakili penyelidikan empirikal merupakan kaedah yang berkesan untuk mengira kesesuaian jumlah sampel yang dikehendaki mengikut populasi kawasan kajian.

Formula untuk menentukan saiz sampel menurut Krejcie et. al. (1970) adalah seperti yang dinyatakan di bawah ini dan pada Jadual 1.

Formula penentuan saiz sampel:

$\mathrm{s}=\mathrm{X} 2 \mathrm{NP}(1-\mathrm{P}) / \mathrm{d} 2(\mathrm{~N}-1)+\mathrm{X} 2 \mathrm{P}(1-\mathrm{P})$

$\mathrm{s}=$ sampel saiz yang diperlukan

$\mathrm{X} 2$ = nilai jadual chi-square untuk 1 darjah kebebasan pada tahap keyakinan yang diinginikan (3.841)

$\mathrm{N}$ = saiz populasi

$\mathrm{P}=$ perkadaran populasi (diandaikan 50 kerana ini akan memberikan ukuran maksimum saiz sampel

$\mathrm{d}=$ tahap ketepatan dinyatakan sebagai perkadaran (05)

Jadual 1. Jadual pengiraan sampel responden

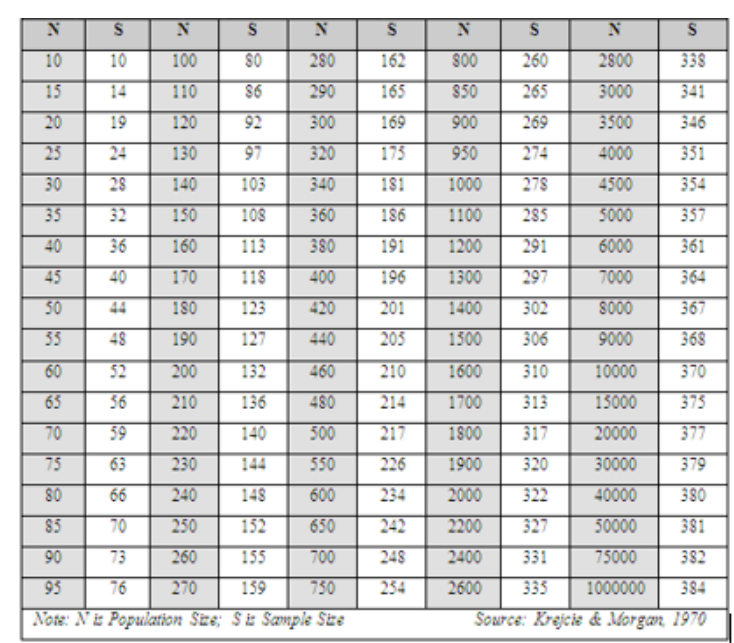

Sumber: Krejcie et. al. (1970) 


\section{Hasil Kajian}

Maklumat demografi penduduk merupakan bahagian yang menghuraikan dan menganalisis data-data profil responden yang telah dipilih iaitu di flat Buluh Kubu dan di kawasan perumahan teres kos rendah. Tujuan analisis profil responden adalah untuk mendapatkan gambaran jenis kelompok yang mendiami kawasan perumahan yang dipilih dan kedudukan sosioekonomi penduduk di perumahan tersebut. Maklumat kelompok yang diperlukan adalah untuk mengetahui kemampuan responden mendiami perumahan yang dipilih dan kedudukan sosioekonomi mereka. Antara maklumat demografi yang diedarkan di dalam borang soal selidik seperti umur, jantina, kewarganegaraan, tahap pendidikan, bilangan isi rumah dan tanggungan, jenis pekerjaan, pendapatan, status, jenis pemilikan, kemampuan pemilikan dan sebagainya seperti pada Jadual 2. Maklumat ini merupakan gambaran sebenar tentang kedudukan sosioekonomi yang merupakan data-data penting dalam kajian penyelidikan yang dijalankan ini.

Jadual 2. Maklumat Demografi Penduduk

\begin{tabular}{|c|c|c|c|c|}
\hline \multicolumn{3}{|l|}{ Ciri-ciri Demografi } & Jumlah & Peratus (\%) \\
\hline \multirow[t]{4}{*}{ Jantina } & \multirow[t]{2}{*}{ Flat Buluh Kubu } & Lelaki & 110 & $57.5 \%$ \\
\hline & & Perempuan & 150 & $42.5 \%$ \\
\hline & \multirow{2}{*}{$\begin{array}{l}\text { Perumahan teres } \\
\text { kos rendah }\end{array}$} & Lelaki & 142 & $46.8 \%$ \\
\hline & & Perempuan & 158 & $53.2 \%$ \\
\hline \multirow{4}{*}{$\begin{array}{l}\text { Status } \\
\text { Kewarganegaraan }\end{array}$} & \multirow[t]{2}{*}{ Flat Buluh Kubu } & Warganegara Malaysia & 248 & $95.8 \%$ \\
\hline & & Bukan Kewarganegaraan & 12 & $4.2 \%$ \\
\hline & \multirow{2}{*}{$\begin{array}{l}\text { Perumahan teres } \\
\text { kos rendah }\end{array}$} & Warganegara Malaysia & 277 & $92.3 \%$ \\
\hline & & Bukan Kewarganegaraan & 23 & $7.7 \%$ \\
\hline \multirow[t]{11}{*}{ Jenis Kaum } & \multirow[t]{5}{*}{ Flat Buluh Kubu } & Melayu & 235 & $90.7 \%$ \\
\hline & & Cina & 14 & $5.4 \%$ \\
\hline & & India & 0 & $0.0 \%$ \\
\hline & & Bangladesh & 6 & $2.7 \%$ \\
\hline & & Indonesia & 3 & $1.2 \%$ \\
\hline & \multirow{6}{*}{$\begin{array}{l}\text { Perumahan teres } \\
\text { kos rendah }\end{array}$} & Melayu & 256 & $85.4 \%$ \\
\hline & & Cina & 4 & $1.3 \%$ \\
\hline & & India & 15 & $5.0 \%$ \\
\hline & & Bangladesh & 6 & $2.0 \%$ \\
\hline & & Indonesia & 18 & $6.0 \%$ \\
\hline & & Arab & 1 & $0.3 \%$ \\
\hline \multirow{8}{*}{$\begin{array}{l}\text { Status } \\
\text { Perkahwinan }\end{array}$} & \multirow[t]{4}{*}{ Flat Buluh Kubu } & Bujang & 95 & $36.8 \%$ \\
\hline & & Berkahwin & 139 & $53.1 \%$ \\
\hline & & Duda/Janda & 15 & $5.8 \%$ \\
\hline & & Balu & 11 & $4.3 \%$ \\
\hline & Perumahan teres & Bujang & 61 & $20.3 \%$ \\
\hline & \multirow{3}{*}{ kos rendah } & Berkahwin & 202 & $67.3 \%$ \\
\hline & & Duda/Janda & 34 & $11.3 \%$ \\
\hline & & Balu & 3 & $1.1 \%$ \\
\hline \multirow{8}{*}{ Umur } & \multirow[t]{4}{*}{ Flat Buluh Kubu } & 20-30 tahun & 82 & $31.7 \%$ \\
\hline & & 31-40 tahun & 46 & $17.8 \%$ \\
\hline & & 41-50 tahun & 44 & $16.6 \%$ \\
\hline & & 51 dan ke atas & 88 & $34.0 \%$ \\
\hline & \multirow{4}{*}{$\begin{array}{l}\text { Perumahan teres } \\
\text { kos rendah }\end{array}$} & 20-30 tahun & 56 & $18.7 \%$ \\
\hline & & 31-40 tahun & 39 & $13.0 \%$ \\
\hline & & 41-50 tahun & 34 & $11.1 \%$ \\
\hline & & 51 dan ke atas & 171 & $57.2 \%$ \\
\hline \multirow[t]{3}{*}{ Sektor Pekerjaan } & \multirow[t]{3}{*}{ Flat Buluh Kubu } & Kakitangan Kerajaan & 26 & $10.0 \%$ \\
\hline & & Kakitangan Swasta & 32 & $12.4 \%$ \\
\hline & & Bekerja Sendiri & 107 & $41.3 \%$ \\
\hline
\end{tabular}


DOI: https://doi.org/10.47405/mjssh.v6i11.1170

\begin{tabular}{|c|c|c|c|c|}
\hline & & $\begin{array}{l}\text { Pelajar } \\
\text { Tidak Bekerja }\end{array}$ & $\begin{array}{l}17 \\
78\end{array}$ & $\begin{array}{l}6.6 \% \\
29.7 \%\end{array}$ \\
\hline & Perumahan teres & Kakitangan Kerajaan & 56 & $18.7 \%$ \\
\hline & kos rendah & Kakitangan Swasta & 70 & $23.3 \%$ \\
\hline & & Bekerja Sendiri & 63 & $21.0 \%$ \\
\hline & & Pelajar & 20 & $6.7 \%$ \\
\hline & & Tidak Bekerja & 91 & $30.3 \%$ \\
\hline Pendapatan & Flat Buluh Kubu & $<$ Kurang daripada & 139 & $58.9 \%$ \\
\hline Bulanan & & RM1200 & 95 & $40.3 \%$ \\
\hline & & RM 1,201- RM4,000 & 2 & $0.8 \%$ \\
\hline & & (B40) & 0 & $0.0 \%$ \\
\hline & & RM4,001- RM8,000 & & \\
\hline & & (M40) & & \\
\hline & & $\begin{array}{l}\text { > Melebihi } \\
\text { RM8,001(T20) }\end{array}$ & & \\
\hline & Perumahan teres & $<$ Kurang daripada & 77 & $27.6 \%$ \\
\hline & kos rendah & RM1,200 & 199 & $71.3 \%$ \\
\hline & & RM1,201- RM4,000 & 3 & $1.1 \%$ \\
\hline & & (B40) & 0 & $0.0 \%$ \\
\hline & & RM4,001- RM8,000 & & \\
\hline & & (M40) & & \\
\hline & & > Melebihi & & \\
\hline & & RM8,001(T20) & & \\
\hline Bilangan Isi & Flat Buluh Kubu & Tiada anak & 100 & $39.2 \%$ \\
\hline Rumah & & $1-5$ orang & 124 & $48.6 \%$ \\
\hline & & $6-10$ orang & 30 & $11.8 \%$ \\
\hline & & 11 orang ke atas & 1 & $0.4 \%$ \\
\hline & Perumahan teres & Tiada anak & 60 & $21.4 \%$ \\
\hline & kos rendah & $1-5$ orang & 168 & $60.0 \%$ \\
\hline & & $6-10$ orang & 51 & $18.2 \%$ \\
\hline & & 11 orang ke atas & 1 & $0.4 \%$ \\
\hline Status Pemilikan & Flat Buluh Kubu & Memiliki rumah sendiri & 189 & $74.1 \%$ \\
\hline & & Menyewa & 66 & $25.9 \%$ \\
\hline & Perumahan teres & Memiliki rumah sendiri & 182 & $60.7 \%$ \\
\hline & kos rendah & Menyewa & 118 & $39.3 \%$ \\
\hline Jenis Pemilikan & Flat Buluh Kubu & Bersama isteri/suami & 129 & $50.8 \%$ \\
\hline & & Persendirian & 55 & $21.7 \%$ \\
\hline & & Warisan Keluarga & 70 & $27.6 \%$ \\
\hline & & Pemberian/hadiah & 0 & $0.0 \%$ \\
\hline & Perumahan teres & Bersama isteri/suami & 75 & $26.5 \%$ \\
\hline & kos rendah & Persendirian & 157 & $55.5 \%$ \\
\hline & & Warisan Keluarga & 50 & $17.7 \%$ \\
\hline & & Pemberian/hadiah & 1 & $0.4 \%$ \\
\hline
\end{tabular}

Berdasarkan Jadual 2 jelas menunjukkan bahawa penduduk di flat Buluh Kubu majoritinya lelaki iaitu sebanyak $57.5 \%$ manakala di kawasan perumahan teres kos rendah majoritinya ialah perempuan iaitu sebanyak 53.2\%. Majoriti yang tinggal di kedua-dua kawasan kajian ini merupakan warganegara Malaysia dengan 95.8\% di flat Buluh Kubu dan sebanyak 92.3\% di kawasan perumahan teres kos rendah. Kaum Melayu merupakan kaum yang paling ramai tinggal di kedua-dua kawasan kajian iaitu sebanyak $90.7 \%$ di flat Buluh Kubu dan $85.4 \%$ di kawasan perumahan teres kos rendah. Manakala terdapat juga kaum-kaum lain yang tinggal di kedua-dua kawasan kajian iaitu kaum Cina, India, Bangladesh, Indonesia dan Arab.

Responden-responden di kawasan kajian merupakan pasangan yang telah berkahwin dengan di flat Buluh Kubu sebanyak 53.1\% manakala di kawasan perumahan teres kos rendah sebanyak $67.3 \%$ responden yang telah mendirikan rumah tangga. Namun begitu terdapat perbezaan yang ketara pada 
umur responden di kedua-dua kawasan kajian. Di flat Buluh Kubu majoriti responden iaitu sebanyak $31.7 \%$ merupakan golongan muda yang berusia antara 20 tahun hingga 30 tahun. Manakala responden di kawasan perumahan teres kos rendah iaitu sebanyak 57.2\% merupakan golongan tua yang berusia 51 tahun dan ke atas. Hal ini kerana jenis perumahan teres kos rendah lebih memberi kemudahan akses kepada golongan tua dengan keadaan fizikal mereka yang tidak berdaya jika tinggal di perumahan flat yang bertingkat seperti di flat Buluh Kubu.

Hal ini selari dengan sektor pekerjaan responden iaitu di flat Buluh Kubu yang majoritinya golongan muda yang menetap di sini merupakan mereka yang bekerja sendiri iaitu sebanyak $41.3 \%$ manakala bagi responden di kawasan perumahan teres kos rendah sebanyak 30.3\% merupakan golongan yang tidak bekerja. Keadaan ini dibuktikan melalui jumlah pendapatan responden iaitu di flat Buluh Kubu sebanyak 58.9\% berpendapatan kurang daripada RM1,200 sebulan manakala sebanyak $71.3 \%$ responden di kawasan perumahan teres kos rendah berpendapatan di antara RM1,201 hingga RM4,000 sebulan yang mereka merupakan golongan B40 iaitu golongan yang berpendapatan sederhana. Responden yang tinggal di kedua-dua kawasan kajian hanya merupakan golongan yang berpendapatan rendah dan sederhana sahaja dan tiada golongan yang berpendapatan tinggi yang mendiami kawasan perumahan ini. Hal ini kerana bersesuaian dengan status perumahan kawasan kajian ialah kawasan perumahan berkos rendah tetapi juga didiami oleh golongan berpendapatan sederhana.

Responden di kedua-dua kawasan kajian memiliki bilangan isi rumah di antara seorang hingga 5 orang iaitu di flat Buluh Kubu sebanyak $48.6 \%$ dan di kawasan perumahan teres kos rendah sebanyak $60.0 \%$. Responden ini memiliki rumah berkenaan dan merupakan pemilik rumah di flat Buluh Kubu sebanyak $74.1 \%$ manakala di kawasan perumahan teres kos rendah sebanyak $60.7 \%$ responden merupakan pemilik kediaman berkenaan. Perumahan di flat Buluh Kubu majoritinya iaitu sebanyak $50.8 \%$ memiliki rumah secara bersama antara suami dan isteri melalui perkongsian pinjaman perumahan atas kapasiti harta sepencarian. Manakala bagi responden di kawasan perumahan teres kos rendah pula majoritinya memiliki rumah secara sendiri tanpa membuat pinjaman bersama dengan pasangan mereka iaitu sebanyak $55.5 \%$ orang responden.

Oleh hal demikian, berdasarkan penerangan tentang ciri-ciri demografi responden di kedua-dua kawasan kajian iaitu di flat Buluh Kubu dan di kawasan perumahan teres kos rendah jelas menunjukkan golongan ini merupakan golongan yang layak mendiami jenis perumahan ini berdasarkan kapasitinya sebagai responden yang berada dalam kumpulan pendapatan rendah. Namun begitu terdapat juga golongan yang berpendapatan sederhana mendiami dan memiliki jenis perumahan kos rendah ini. Selain itu, faktor status perkahwinan, umur, sektor pekerjaan, pendapatan bulanan, bilangan isi rumah, status pemilikan rumah dan jenis pemilikan rumah memainkan peranan penting mengenai keadaan responden yang menetap di perumahan ini. Hal ini selaras dengan Wan Syamuri (2004) yang menyatakan bahawa terdapat enam (6) pembolehubah utama yang dikenalpasti mempengaruhi kemampuan golongan berpendapatan rendah untuk memiliki rumah kos rendah ialah pendapatan isi rumah, perbelanjaan isi rumah, jenis-jenis pekerjaan, tahap pendidikan, isi rumah yang bekerja dan jumlah bayaran bulanan perumahan.

\section{Perbincangan Kajian}

\section{Kriteria Perumahan}

Kriteria perumahan merujuk pada analisis yang berkaitan dengan faktor-faktor tahap kepuasan penduduk terhadap kriteria perumahan kos rendah iaitu flat Buluh Kubu dan di kawasan perumahan teres kos rendah yang dapat mempengaruhi kepuasan dan pembelian terhadap rumah yang mereka diami. Terdapat pelbagai kriteria perumahan yang menjadi faktor tahap kepuasan penduduk terhadap rumah yang mereka diami tetapi di borang soal selidik ini hanya menyenaraikan 11 kriteria perumahan untuk responden memilihnya mengikut tahap keutamaan kepuasan perumahan. Faktor-faktor kriteria perumahan yang dimaksudkan di dalam borang soal selidik ialah kemudahan asas yang disediakan di dalam perumahan, reka bentuk dalaman, saiz dan sebagainya yang berkaitan dengan masalah di dalam dua perumahan yang dipilih. 
Jadual 3 menunjukkan analisis yang telah dijalankan dan data yang diperoleh mengenai faktor-faktor tahap kepuasan penduduk terhadap kriteria-kriteria perumahan di kedua-dua kawasan kajian. Analisis yang dijalankan menggunakan analisis kekerapan dan skala likert bagi memperoleh jumlah skor dan purata skor bagi setiap kriteria perumahan.

Jadual 3. Analisis faktor-faktor yang mempengaruhi tahap kepuasan penduduk terhadap kriteria-kriteria perumahan

\begin{tabular}{|c|c|c|c|c|c|c|c|c|}
\hline \multirow{2}{*}{$\begin{array}{l}\text { Kriteria-Kriteria } \\
\text { Perumahan }\end{array}$} & \multirow{2}{*}{$\begin{array}{l}\text { Jenis Rumah } \\
\text { Kos Rendah }\end{array}$} & \multicolumn{5}{|c|}{ Skala } & \multirow{2}{*}{$\begin{array}{l}\text { Jumlah } \\
\text { Skor }\end{array}$} & \multirow{2}{*}{$\begin{array}{l}\text { Purata } \\
\text { Skor }\end{array}$} \\
\hline & & 1 & 2 & 3 & 4 & 5 & & \\
\hline \multirow{4}{*}{$\begin{array}{l}\text { 1. Apakah penduduk } \\
\text { berpuas hati dengan } \\
\text { kemudahan asas yang } \\
\text { disediakan? }\end{array}$} & Flat Buluh Kubu & 3 & 6 & 29 & 221 & 1 & 260 & 3.812 \\
\hline & Perumahan & 0 & 70 & 154 & 73 & 3 & 300 & 3.030 \\
\hline & Teres Kos & & & & & & & \\
\hline & Rendah & & & & & & & \\
\hline \multirow{4}{*}{$\begin{array}{l}\text { 2. Adakah anda } \\
\text { perpuas hati dengan } \\
\text { jumlah tempat letak } \\
\text { kereta yang } \\
\text { disediakan? }\end{array}$} & Flat Buluh Kubu & 11 & 23 & 221 & 4 & 1 & 260 & 2.850 \\
\hline & Perumahan & 0 & 121 & 157 & 18 & 4 & 300 & 2.683 \\
\hline & Teres Kos & & & & & & & \\
\hline & Rendah & & & & & & & \\
\hline \multirow{4}{*}{$\begin{array}{l}\text { 3. Adakah anda } \\
\text { berpuas hati dengan } \\
\text { ruang balkoni dan } \\
\text { ruang di depan rumah? }\end{array}$} & Flat Buluh Kubu & 6 & 149 & 96 & 9 & 0 & 260 & 2.415 \\
\hline & Perumahan & 4 & 148 & 120 & 25 & 3 & 300 & 2.583 \\
\hline & Teres Kos & & & & & & & \\
\hline & Rendah & & & & & & & \\
\hline \multirow{4}{*}{$\begin{array}{l}\text { 4. Adakah anda } \\
\text { berpuas hati dengan } \\
\text { saiz unit dapur? }\end{array}$} & Flat Buluh Kubu & 7 & 7 & 57 & 187 & 2 & 260 & 3.654 \\
\hline & Perumahan & 1 & 7 & 38 & 203 & 5 & 300 & 3.987 \\
\hline & Teres Kos & & & & & 1 & & \\
\hline & Rendah & & & & & & & \\
\hline \multirow{8}{*}{$\begin{array}{l}\text { 5. Adakah anda } \\
\text { berpuas hati dengan } \\
\text { saiz ruang tamu yang } \\
\text { disediakan? } \\
6 . \text { Adakah anda } \\
\text { berpuas hati dengan } \\
\text { saiz ruang makan yang } \\
\text { disediakan? }\end{array}$} & Flat Buluh Kubu & 6 & 4 & 15 & 233 & 2 & 260 & 3.850 \\
\hline & Perumahan & 2 & 2 & 31 & 209 & 5 & 300 & 4.050 \\
\hline & Teres Kos & & & & & 6 & & \\
\hline & Rendah & & & & & & & \\
\hline & Flat Buluh Kubu & 6 & 7 & 189 & 55 & 0 & 260 & 3.104 \\
\hline & Perumahan & 2 & 3 & 72 & 148 & 7 & 300 & 3.970 \\
\hline & Teres Kos & & & & & 5 & & \\
\hline & Rendah & & & & & & & \\
\hline \multirow{4}{*}{$\begin{array}{l}\text { 7. Adakah anda } \\
\text { berpuas hati dengan } \\
\text { bilangan bilik tidur } \\
\text { yang disediakan? }\end{array}$} & Flat Buluh Kubu & 8 & 4 & 3 & 242 & 3 & 260 & 3.876 \\
\hline & Perumahan & 1 & 2 & 66 & 172 & 5 & 300 & 3.953 \\
\hline & Teres Kos & & & & & 9 & & \\
\hline & Rendah & & & & & & & \\
\hline \multirow{4}{*}{$\begin{array}{l}\text { 8. Adakah anda } \\
\text { berpuas hati dengan } \\
\text { saiz bilik tidur yang } \\
\text { disediakan? }\end{array}$} & Flat Buluh Kubu & 6 & 5 & 5 & 241 & 3 & 260 & 3.884 \\
\hline & Perumahan & 0 & 5 & 58 & 164 & 7 & 300 & 4016 \\
\hline & Teres Kos & & & & & 3 & & \\
\hline & Rendah & & & & & & & \\
\hline \multirow{4}{*}{$\begin{array}{l}\text { 9. Adakah anda } \\
\text { berpuas hati dengan } \\
\text { bilangan tandas yang } \\
\text { disediakan? }\end{array}$} & Flat Buluh Kubu & 7 & 2 & 7 & 242 & 2 & 260 & 3.884 \\
\hline & Perumahan & 3 & 2 & 72 & 159 & 6 & 300 & 3.930 \\
\hline & Teres Kos & & & & & 4 & & \\
\hline & Rendah & & & & & & & \\
\hline \multirow{4}{*}{$\begin{array}{l}\text { 10. Adakah anda } \\
\text { berpuas hati dengan } \\
\text { ruangan membasuh? }\end{array}$} & Flat Buluh Kubu & 8 & 40 & 202 & 8 & 2 & 260 & 2.830 \\
\hline & Perumahan & 2 & 4 & 200 & 83 & 1 & 300 & 3.323 \\
\hline & Teres Kos & & & & & 1 & & \\
\hline & Rendah & & & & & & & \\
\hline 11. Adakah anda & Flat Buluh Kubu & 11 & 5 & 4 & 238 & 2 & 260 & 3.826 \\
\hline
\end{tabular}



DOI: https://doi.org/10.47405/mjssh.v6i11.1170

$\begin{array}{lllllllll}\begin{array}{l}\text { berpuas hati dengan } \\ \text { taman permainan } \\ \text { disediakan di kawasan } \\ \text { rumah? }\end{array} & \begin{array}{l}\text { Perumahan } \\ \text { Teres Kos }\end{array} & 109 & 161 & 7 & 22 & 1 & 300 & 1.816 \\ \text { Rendah } & & & & & & & \\ \end{array}$
rumah?

Berdasarkan Jadual 3 menunjukkan bahawa faktor-faktor kriteria perumahan yang mencatatkan skor min tertinggi adalah di flat Buluh Kubu iaitu 3.884 untuk tahap kepuasan terhadap saiz bilik tidur dan bilangan tandas yang disediakan. Melalui pemerhatian dan temu bual tidak formal, responden menyatakan bahawa bilik tidur dan tandas sudah cukup selesa bersesuaian dengan harga rumah yang dibeli atau disewa. Manakala perumahan teres kos rendah pula untuk purata yang mencatatkan min tertinggi ialah 4.050 tahap kepuasan mereka terhadap saiz ruang tamu yang disediakan. Responden menyatakan bahawa saiz ruang tamu memadai dengan harga dan muat antara 10 orang hingga 12 orang.

Oleh yang demikian, min yang tertinggi adalah tahap kepuasan responden terhadap rumah yang mereka diami dan tiada masalah terhadap kriteria yang dihuni. Kriteria-kriteria perumahan seterusnya yang mencapai tahap kepuasan penduduk di flat Buluh Kubu ialah berpuas hati terhadap bilangan bilik tidur dengan min skor 3.876 kerana bersesuaian dengan bilangan isi rumah responden yang tinggal di perumahan ini yang majoriti bilangan isi rumah ialah seramai seorang hingga 5 orang isi rumah manakala min skor tinggi kedua di perumahan teres kos rendah dengan bilangan min skor 4.050 adalah berpuas hati terhadap saiz bilik tidur yang terdapat di perumahan tersebut. Faktor ketiga terpenting yang memberi kepuasan baik di flat Buluh Kubu dengan min skor 3.850 adalah keadaan ruang tamu yang selesa bersesuaian dengan saiz rumah manakala perumahan teres kos rendah adalah berpuas hati dengan saiz dapur dengan min skor 3.987. Walau bagaimanapun, flat Buluh Kubu tidak mencapai tahap kepuasan penduduk kerana mengikut pendapat responden bahawa dapur mereka sedikit kecil. Oleh demikian, faktor yang paling sedikit mencatat skor purata flat Buluh Kubu dengan skor 2.415 adalah tidak kepuasan terhadap saiz balkoni kerana mengikut pemerhatian di kawasan kajian saiz balkoni agak kecil dan sempit menyebabkan penduduk tidak mempunyai ruang untuk bersantai manakala perumahan teres kos rendah pula dengan min skor yang paling sedikit adalah ketidakpuasan hati terhadap taman permainan dengan skor 1.816 kerana taman permainan di taman perumahan tersebut tidak sempurna, alat-alat permainan yang rosak dan taman yang tidak diselenggara. Hal ini menyebabkan rungutan daripada penduduk yang tinggal di situ.

Terdapat enam (6) cadangan untuk penambahbaikan perumahan kos rendah iaitu elemen reka bentuk, penggunaan bahan binaan, pengawasan hasil kerja yang bermutu, penyelenggara dan pengurusan bangunan dan Penglibatan pihak berkuasa.

\section{Elemen Reka Bentuk}

Elemen reka bentuk merupakan perkara yang penting dalam kriteria perumahan kerana kriteria ini menjadi perkara utama kepada pembeli yang ingin membeli rumah seperti unit dalaman, ukuran unit, susun atur dalaman unit dan elemen yang berkaitan dengan kriteria perumahan. Oleh itu, pemaju dan badan profesional yang terlibat harus memainkan peranan utama dalam menghasilkan saiz ruang mengikut garis panduan dan mencapai tahap kepuasan penduduk supaya susun atur yang direka bentuk itu bernilai untuk dibeli oleh penduduk (Ai et al., 2011). Pemaju dan badan profesional yang terlibat perlu mementingkan kriteria perumahan seperti bilangan dan saiz bilik tidur, ruang tamu, dapur dan balkoni dalam menentukan kualiti flat kos rendah (Akta 118, 2020). Antara garis panduan yang boleh diikuti ialah menerusi Akta Pemajuan Perumahan (Kawalan dan Pelesenan) 1966 (Akta 118) dan Peraturan-Peraturan (Akta 118, 2020).

Mengikut data analisis menunjukkan bahawa sebanyak 149 daripada 260 saiz sampel responden flat Buluh Kubu dan 148 daripada 300 saiz sampel di kawasan perumahan teres kos rendah menyatakan bahawa tidak berpuas hati terhadap saiz balkoni, dapur dan kawasan dobi. Hal ini kerana ruang balkoni agak sempit dan kecil sehingga menimbulkan isu dari tahun 2004 sehingga ke tahun 2021. Oleh hal demikian, pelbagai rancangan penambahbaikan pada unit standard khas dalam usaha untuk 
meningkatkan tahap kepuasan penduduk untuk kriteria perumahan kos rendah telah dikenal pasti dan disenaraikan seperti berikut (Ai et al., 2011):

i. Perlu mempunyai dapur yang lebih besar pada pembangunan perumahan kos rendah akan datang mengikut garis panduan terkini 2021.

ii. Mempunyai saiz balkoni yang lebih luas agar penduduk dapat menggunakannya untuk pelbagai urusan.

iii. Mempunyai bilik mandi yang lebih.

iv. Meningkatkan ketinggian minimum ke lantai dari 2800m sehingga 3000mm.

\section{Penggunaan Bahan Pembinaan}

Pengawalan harga kos bahan binaan perlu dikawal supaya pembinaan kualiti perumahan kos rendah mempunyai bahan binaan berkualiti yang dapat memberi tahap kepuasan mereka terhadap struktur bangunan. Bahan binaan yang berkualiti akan menghasilkan bangunan perumahan yang elok dan sempurna. Cadangan dari Ai et al. (2011). bahawa kawalan pembelian bahan binaan oleh pemaju haruslah dikawal oleh pihak kerajaan dan mengikut garis panduan di antara semua pihak berwajib termasuk Kementerian Perumahan, Kerajaan Tempatan dan Jabatan Perumahan Negara.

\section{Pengawasan Hasil Kerja Yang Bermutu}

Pengawasan dan pengawalan hasil kerja yang bermutu terhadap pekerja sangat membantu dalam menghasilkan perumahan kos rendah yang berkualiti. Kebanyakan hasil kerja yang tidak berkualiti yang dilakukan oleh pekerja atau buruh tidak mahir disebabkan oleh mutu kerja yang rendah dan tidak berpengalaman. Oleh itu, cadangan dalam penambahbaikan masalah ini adalah dengan menggunakan kaedah Sistem Bangunan Perindustrian (Industrialised Building System-IBS) dalam industri pembinaan kos rendah kerana Sistem IBS ini merupakan salah satu sistem yang telah digunakan di negara maju seperti di Amerika Syarikat, Jepun dan Australia (Mohd Nasrun et al., 2004). Antara kelebihan penggunaan kaedah ini ialah:

i. Dapat mengurangkan kegunaan tenaga buruh tidak mahir.

ii. Dapat menjamin kualiti pembinaan dijaga dengan baik.

iii. Kaedah pengurusan yang lebih baik, berkualiti dan pembinaan yang lebih pantas dan cekap.

iv. Dapat mendorong Penyelidikan dan Pembangunan (Research and Development- R\&D) untuk pengeluaran bahan binaan tempatan yang sesuai dengan iklim serta keperluan negara.

v. Penggunaan bahan binaan atau struktur yang digunakan dapat menurunkan harga kos bahan binaan yang secara tidak langsung dapat menurunkan harga rumah kos rendah yang berkualiti.

\section{Penyelenggaran dan Pengurusan Bangunan}

Menguatkan penyelenggaraan dan pengurusan bangunan secara berterusan adalah satu penambahbaikan dalam meningkatkan tahap kepuasan penduduk terhadap pengurusan pihak yang mengurus. Menurut Hashim et al. (2012) mendefinisikan bahawa penyelenggaraan merupakan aktiviti yang diperlukan secara berterusan untuk menjaga segala kemudahan yang berkaitan dengan perumahan kos rendah.

\section{Penglibatan Pihak Berkuasa}

Cadangan untuk melakukan penambahbaikan tahap kepuasan penduduk kos rendah adalah dengan melibatkan kerjasama pihak berkuasa. Ai et al. (2011) menyatakan bahawa di Malaysia, perancangan dan standard minimum perumahan kos rendah harus dikendalikan oleh pelbagai jenis agensi kerajaan termasuk Kementerian Perumahan dan kerajaan Tempatan serta Jabatan Perumahan Negara. Kerjasama semua pihak adalah untuk memperbaiki dan menjayakan perlaksanaan dasar dan piawaian untuk meningkatkan kualiti perumahan kos rendah. 


\section{Kesimpulan}

Secara kesimpulannya, kajian ini dilakukan adalah untuk memenuhi keperluan perumahan kos rendah melalui tahap kepuasan penduduk. Selain itu, kajian ini juga untuk menyelesaikan masalah utama yang terdapat di perumahan kos rendah supaya melalui kajian ini pemaju dapat memberi perhatian untuk memenuhi keperluan dan kepuasan penduduk pada masa akan datang. Antara permasalahanpermasalahan utama yang ditemui adalah ketidakpuasan penduduk terhadap balkoni, ruang dobi, taman permainan, sistem penyelenggaraan tong sampah, atap, perilaku penduduk yang tidak menjaga kebersihan dan bangunan rumah yang pecah serta retak.

Dengan adanya cadangan penambahbaikan yang telah dikemukakan, kajian ini dapat menyelesaikan masalah penduduk terhadap faktor ketidakpuasan mereka terhadap perumahan kos rendah melalui tindakan pihak berkuasa dalam menjalankan tanggungjawab mereka untuk menyelesaikan permasalahan ini. Hal ini juga dapat mengelakkan persepsi orang ramai terhadap perumahan kos rendah kerana di Malaysia, yang sering dikaitkan dengan masalah kualiti. Justeru itu, pelbagai usaha dan tanggungjawab pihak terlibat terutama pemaju perlu memberi perhatian dalam membangunkan perumahan kos rendah yang sesuai dengan harga serta bahan yang berkualiti.

Terutamanya dalam keadaan pandemik Covid-19 ini, permasalahan berkaitan isu perumahan kos rendah turut menerima kesannya. Hal ini disokong oleh Norazmawati (2021a) yang menyatakan bahawa terdapat tiga tekanan perumahan pasca pandemik Covid-19 iaitu lambakan pasaran perumahan, pasaran perumahan merosot pada jangka pendek dan sederhana dan ramalan pasaran perumahan pada masa hadapan. Pemulihan industri perumahan yang cepat dijangkakan akan mengambil masa sehingga 3 tahun selepas pandemik Covid-19 berakhir dengan syarat terdapatnya kerjasama yang padu antara pihak kerajaan dan semua pihak yang berkaitan dalam industri perumahan Norazmawati (2021b).

\section{Penghargaan}

Penghargaan kepada Mega Jati Academy untuk Geran Industri dengan kod projek: AO2263 untuk penulis di Pusat Pengajian Perumahan, Bangunan dan Perancangan, Universiti Sains Malaysia, Pulau Pinang, Malaysia yang menyokong penyelidikan ini.

\section{Rujukan}

Ai, T.G., Ahmad, T. \& Yahaya. (2011). Public Low-Cost Housing in Malaysia: Case Studies on PPR Low-Cost Flats in Kuala Lumpur. Journal of Design and Built Environment, 8(1).

Akta Pemajuan Perumahan (Kawalan dan Pelesenan) 1966 (Akta 118) dan Peraturan-Peraturan. International Law Book Services. Hingga $15^{\text {th }}$ Februari 2020.

Gabriel \& Bowling (2004). Quality of life from the perspectives of older people. Ageing and Society, 24(5), $675-691$.

Ghani, S. \& Nurwati, B. (2012). Quality of life of residents in urban neighbourhoods of Pulau Pinang, Malaysia. Journal of Construction in Developing Countries, 17(2), 117-123.

Hashim, A. E., Samikon, S. A., Nasir, N. M., \& Ismail, N. (2012). Assessing Factors Influencing Performance of Malaysian Low-Cost Public Housing in Sustainable Environment. Procedia Social and Behavioral Sciences, 50, 920-927.

Krejcie, R.V., \& Morgan, D.W. (1970). Determining Sample Size for Research Activities. Educational and Psychological Measurement.

Liu, A. M. M. (1999). Residential Satisfaction in Housing Estate: A Hong Kong Perspective. Automation in Construction, 8(4).

Mohammad, A.M., Mansor, I. \& Yong, R.R. (2010). Assessment of Residential Satisfaction in Newly Designed Public Low-Cost Housing in Kuala Lumpur, Malaysia. Habitat International, 34, 1827. 
Mohd Nasrun, M.N., Ahmad Tarmizi, H., Zuhairi, A.H., Kamarul,A., Mohamad Kamar \& Yusnizam, B. (2014). Improving Integrated Practice through Building Information Modeling-Integrated Project Delivery (BIM-IPD) for Malaysian Industrialised Building System (IBS) Construction Projects. Malaysian Construction Research Journal, 15(2).

Norazmawati M.S. (2007). "Kemampuan Pemilikan Rumah Kos Rendah di Kuala Lumpur". PhD Tesis. Pulau Pinang: Universiti Sains Malaysia.

Norazmawati M.S. (2021a). Tekanan Perumahan Pasca Pandemik Covid-19 Terhadap Kemampuan Perumahan. Jurnal Dunia Pengurusan, 3(2), 59-66.

Norazmawati M.S. (2021b). The impact of the Covid-19 Pandemic in Pulau Pinang, in the Context of the Housing Industry. Sumerianz Journal of Social Science, 3(11), 137-141.

Russell, J. (2008). Residential Satisfaction of Elderly Tenants in Apartment Housing. Social Indicator Research, 89, 421-437.

Shadiya. (2016). The use of residents' satisfaction index in selective rehabilitation of urban core residential areas in developing countries. International Review for Environmental Strategies, 6(1), $137-152$.

Wan Syamuri Bin Wan Mohd. @ Wan Mohd. Nawi. (2004). Perlaksanaan dan Kepuasan Perumahan Kos Rendah Di Kota Bharu, Kelantan. Tesis Master. Universiti Putra Malaysia.

Zadkarim, S. \& Emari, H. (2011). Determinants of Satisfaction in Apartment Industry: Offering A Model. Https://Www.Semanticscholar.Org/Paper/Determinants-Of-Satisfaction-In-ApartmentIndustry\%3a-Zadkarim-Emari/71f3d866da5d8a680f927e4fcf51e3aeb2ff7338 